\title{
Trace elements and congenital abnormalities
}

\section{By R. B. Williams, The Rowett Research Institute, Bucksburn, Aberdeen $A B 29 S B$}

The list of elements essential to processes of mammalian life has been considerably increased in the past few years by the addition of chromium, nickel, silicon, tin and vanadium (Mertz, 1974). Although it is generally accepted that fluorine has a role in reducing the incidence of dental caries, no other biological function for this element was known until Messer, Armstrong \& Singer (1972) showed that an impairment of fertility in female mice occurred when these animals were maintained on low-F diets. The role of the other 'newer trace elements' in reproductive processes is largely unexplored. For this reason, and that of brevity, this paper is restricted to the consideration of the effects of maternal deficiencies of copper, manganese and zinc on the developing mammalian embryo or foetus and on the postnatal sequels of such deficiencies.

Copper deficiency in sheep, and particularly maternal deficiency which leads to the disease 'swayback' (enzootic ataxia) in lambs is a costly problem. There are also suspicions that $\mathrm{Cu}$ deficiency may be involved in some instances of poor reproductive performance in cattle, but the economic significance of this situation has not been adequately explored. In humans, most studies have shown that infants and young children appear to be most at risk (Underwood, I971).

A deficiency of $\mathrm{Mn}$, of natural occurrence, has not unequivocally been demonstrated in ruminants, but pigs and poultry may be so affected. In humans, reports of Mn deficiency are rare, but Xilinas \& Lagarde (1975) suggest that a seasonal incidence of congenital hip dislocation in Brittany may be related to a low maternal $\mathrm{Mn}$ intake. In contrast to these two elements, there are widespread reports of $\mathrm{Zn}$ deficiency. Its natural occurrence in pigs (Tucker \& Salmon, I955) is well-known and is characterized by the skin disorder of parakeratosis. In humans, the discovery of a naturally occurring $\mathrm{Zn}$ deficiency, initially in underprivileged communities (Prasad, Miale, Farid, Sandstead, Schulert \& Darby, 1963) has been followed by the findings of Hambidge, Hambidge, Jacobs \& Baum (1972) that a deficiency of $\mathrm{Zn}$ occurs in infants and children in the United States, chiefly in low income groups. The relevance of these mineral deficiencies to social or economic circumstances is, therefore, well founded.

\section{The physical signs of deficiency}

The dominant feature of maternal deficiencies of $\mathrm{Cu}, \mathrm{Mn}$ or $\mathrm{Zn}$ is the adverse effect exerted on the development of the central nervous system and its associated structures in the developing foetus. A close second would be the high incidence of skeletal anomalies. 
The best known example of the effect of maternal $\mathrm{Cu}$ deficiency on foetal brain development is that in sheep, when, in the neonatal lamb, a widespread encephalopathy occurs with demyelination and cavitation of the cerebrum in the worst affected animals (Innes \& Shearer, 1940). In guinea pigs born to Cu-deficient mothers, the cerebral tissue appears oedematous and cerebellar tissue may be lacking (Everson, Tsai \& Wang, 1967). Rat pups, under similar circumstances, appear to be less severely affected but, even so, focal areas of necrosis may be apparent in the brain (Carlton \& Kelly, 1969).

Those animals born to $\mathrm{Cu}$-deficient mothers which survive long enough for further study frequently exhibit behavioural changes. Apart from the occurrence of ataxia, which may be regarded as the most severe manifestation, there may be milder locomotor difficulties in addition to signs such as tremors and a constant bobbing of the head (Everson et al. 1967). An incidence of priapism in male rats, somewhat catatonic behaviour and, conversely, the ease with which these animals could be stimulated to rush about by the sound of running water all follow $\mathrm{Cu}$ deprivation in utero (Carlton \& Kelly, 1969). Female rats born to mothers receiving I $\mathrm{mg} \mathrm{Cu} / \mathrm{kg}$ diet and reared under similar conditions were easily disturbed and were difficult to handle (R. B. Williams, unpublished observations). A loss of aggressiveness may also be noted (DiPaolo \& Newberne, 1972).

An unexplained feature of $\mathrm{Cu}$ deprivation in the newborn is a change in the vascularity of the cerebral cortex (Everson et al. 1967). C. F. Mills and I also observed vascular changes in the cortex of 'swayback' lambs; the vessels appeared engorged and there was some evidence of subdural haemorrhage. An unexpected finding was the comparatively high tolerance of these animals to intravenous barbiturate administration.

The incidence of vascular changes in the brain may be related to the known adverse effects of $\mathrm{Cu}$ deficiency on the integrity of collagenous and connective tissues. Haemorrhages, presumably due to arterial fragility, occur in the newborn, and the occurrence of abdominal herniae (O'Dell, Hardwick \& Reynolds, I96r) appears related to defective connective tissue formation.

Skeletal defects are attributed to defective calcification as a consequence of anomalies in the organic matrix. Rarefaction and weakness of the bone, as shown by bowing of the legs, is an almost inevitable consequence.

An interesting observation of O'Dell et al. (1961) is the paucity of hair follicles in the skin of the Cu-deficient rat pup.

The effects of less severe $\mathrm{Cu}$ deficiency in utero do not appear to have been studied, and it is considered that an investigation of the behavioural changes noted earlier under conditions where improved postnatal survival is likely, may prove rewarding.

Severe Mn deficiency leads to a high proportion of foetal deaths or short postnatal survival times. Skeletal anomalies and ataxia are common postnatal signs (Hill, Holtkamp, Buchanan \& Rutledge, 1950; Everson, Hurley \& Geiger, 1959; Rojas, Dyer \& Cassatt, 1965).

Unlike the ataxia of $\mathrm{Cu}$ deficiency, that due to maternal Mn deficiency is not 
explained by any gross lesion of the central nervous system, and the unique nature of the lesion responsible is revealed by the studies of Hurley, Everson and their associates (Hurley \& Everson, 1959; Hurley, Wooten, Everson \& Asling, 1960; Shrader \& Everson, 1967) that postural defects in the offspring of Mn-deficient mothers are the consequence of the defective development of the otoliths of the inner ear. It is important, however, to distinguish the effects of this anomaly from those difficulties of motion which may arise from the effects of Mn deficiency on the skeleton. These may include shortening of the bones of the legs, enlarged hock joints, or, as in the nutritional chondrodystrophy of the chick, displacement of the epiphyseal cartilage. In many instances, attempts at motion may be attended by pain (Underwood, 1971).

Other effects of $\mathrm{Mn}$ deficiency in utero include hypoplasia or aplasia of pancreatic tissue and abnormal glucose tolerance in guinea pigs (Shrader \& Everson, 1968; Everson \& Shrader, r 968).

The dramatic effects of maternal $\mathrm{Zn}$ deprivation, in the rat, on embryonic and foetal development is shown by the work of Hurley \& Swenerton (1966). Almost every organ or tissue in the body is affected. Even short-term deficiencies of $\mathrm{Zn}$ cause a high incidence of lesions (Hurley, Gowan \& Swenerton, 1971). When $\mathrm{Zn}$ deficiency is imposed from day 4 to day 12 of pregnancy nearly one-third of all fullterm foetuses are malformed; over the whole course of pregnancy the incidence of malformations is $90 \%$, and nearly one half of these foetuses have gross malformations of the brain, including hydrocephalus, anencephalus or exencephalus. Other defects, in greatest number, include cleft palate, micro- or anophthalmia, micro- or agnathia, clubbed hind legs and deformities of the tail, lungs and urogenital system.

The pattern of nervous system malformations is described in detail by Hurley \& Shrader (1972). Of considerable interest is the occurrence of stenosis or occlusion of the passage between the aqueduct of Sylvius and the caudal end of the third ventricle. The association of this type of defect with hydrocephalus in vitamin $B_{12}$ deficiency is noted by Newberne \& O'Dell (1959).

The association of maternal $\mathrm{Zn}$ deficiency with malformations of the foetus is not, however, clearly predictable. Apgar ( 1968 ) found parturition in Zn-deficient rats to be prolonged and difficult, but there were no malformations. The occurrence of malformations could not be related to foetal $\mathrm{Zn}$ levels at the termination of pregnancy (R. B. Williams, unpublished observations). It would appear that the incidence of malformations may be influenced, not only by dietary $\mathrm{Zn}$ content, but by differences in the ability of the mother to transfer $\mathrm{Zn}$ to the embryo or foetus at critical periods of development and possibly by other dietary factors (see later).

The effects of severe maternal $\mathrm{Zn}$ deficiency clearly preclude any study of postnatal animals. When a less severe $\mathrm{Zn}$ deficiency was imposed survival to weaning age improved as the dietary $\mathrm{Zn}$ content was increased (Williams, Demertzis \& Mills, 1973). A mild prenatal $\mathrm{Zn}$ deficiency was shown to affect the rate but not the level of learning in young rats (Oberleas, Caldwell \& Prasad, 1972), 
but this effect was significant only in offspring from larger litters and may reflect an increased state of $\mathrm{Zn}$ depletion.

\section{Biochemical aspects of deficiency}

Copper deficiency, unlike that of $\mathrm{Zn}$, results in a general depletion of the $\mathrm{Cu}$ content of organs and tissues, with the consequence that the activity of $\mathrm{Cu}$ dependent enzymes diminishes. A decline in cytochrome oxidase $(E C$ r.9.3.1) activity occurs in the brains of Cu-deficient lambs (Howell \& Davison, 1959; Mills \& Williams, 1962). Histochemical examination of the central nervous system of lambs shows that the large neurones of the red nucleus and the grey matter of the spinal cord have reduced activity of this enzyme (Fell, Mills \& Boyne, 1965). A reduction in activity of cytochrome oxidase results in defective phospholipid synthesis (Gallagher \& Reeve, 1971) and it seems that the gross pathological changes in the Cu-deficient brain follow from this defect in terminal oxidative capacity.

More subtle behavioural changes in postnatal animals may reflect a general inability to detoxify biogenic amines as a consequence of a diminution in nonspecific Cu-dependent amine oxidases.

Defects in connective tissue formation and in the formation of the collagenous matrix of bone appear to be related to the decrease in activity of the enzyme lysyl oxidase ( $E C$ 1.4.3.4) which is involved in the oxidative deamination of lysyl residues before cross-linking of collagen or elastin chains (Chou, Savage \& O'Dell, 1969; Siegel, Pinnell \& Martin, 1970).

Few Mn metalloenzymes appear to exist. Pyruvate carboxylase (EC 6.4.1.1) contains $4 \mathrm{~mol} \mathrm{Mn} / \mathrm{mol}$ enzyme, but when $\mathrm{Mn}$ is replaced by magnesium little change in the catalytic properties occurs (Scrutton, Griminger \& Wallace, 1972). It would seem therefore that defects arising from $\mathrm{Mn}$ deficiency are not attributable to a reduction in the activity of this enzyme.

The role of $\mathrm{Mn}$ in foetal development appears to be related to its involvement in mucopolysaccharide synthesis. A reduced mucopolysaccharide content occurs in the bones of $\mathrm{Mn}$-deficient chicks and guinea pigs born to Mn-deficient mothers (Leach, 1960; Tsai \& Everson, 1967). This defect arises from a specific need for $\mathrm{Mn}$ in the activation of glycosyltransferases (Leach, 1971) and a deficiency of $\mathrm{Mn}$ leads to defective or retarded synthesis of mucopolysaccharides (particularly chondroitin sulphate) and glycoproteins. Anomalies in the skeleton and in otolith formation in Mn deficiency are thus attributable to the requirement for $\mathrm{Mn}$ in the normal development of the organic matrix before calcification.

The possible involvement of $\mathrm{Mn}$ in gene expression is indicated by the report of Erway, Hurley \& Fraser (1966) that a genetic defect in otolith formation in the pallid ( $p a)$ mutant strain of mouse is prevented by high dietary $\mathrm{Mn}$ supplementation, though no effect on coat colour occurs (Hurley, 1968).

A deficiency of $\mathrm{Zn}$ results in a wide range of metabolic disturbances (Underwood, 1971) which include defects in DNA, RNA and protein synthesis or 
catabolism. Although many Zn-containing enzymes exist, no lesion is positively identified with a diminution in activity of any enzyme, which is consonant with findings that changes in tissue $\mathrm{Zn}$ content are generally small.

Hurley \& Shrader (1972) suggest that $\mathrm{Zn}$ deficiency influences foetal development by its effect on nucleic acid synthesis; more specifically, a prolongation of the mitotic interval and a reduced number of early neural tube cells would produce a wide spectrum of abnormalities. An alternative hypothesis (Chesters, 1974) that $\mathrm{Zn}$ may be involved in gene expression merits considerable attention, although it may be thought that this would result in a more random effect on the developing foetus than is apparent. A very early effect of $\mathrm{Zn}$ deficiency is to cause abnormal development of preimplantation rat ova (Hurley \& Shrader, 1975) at which stage the demand for $\mathrm{Zn}$ and expression of gene potential are both of a very low order.

Although a considerable emphasis is given to the role of $\mathrm{Zn}$ in DNA synthesis, it is suggested by O'Dell (1974) that the effects observed are secondary to a reduction in the rate of cell division. Falchuk, Fawcett \& Vallee (1975) found that DNA synthesis was not a limiting factor in the division of $\mathrm{Zn}$-deficient Euglena gracilis and suggest a block in the $G_{2}$ phase of the cell cycle.

Anomalies in the mitotic index of tissues of young $\mathrm{Zn}$-deficient rats were found by Fell, Leigh \& Williams (1973). These changes appear to be tissue-specific. The mitotic index of the liver was unchanged by $\mathrm{Zn}$ deficiency; that of the epidermis was lower, while the mitotic indices of the pancreas and duodenum were increased. Calculation of the mitotic and intermitotic times of cells of the Zn-deficient oesophagus (Dinsdale \& Williams, I 977) showed that those times are characteristic of the epithelium of the lower gut, a finding that appears to confirm the view of Chesters (1974) that dedifferentiation of the genetic potential of the cell may occur in $Z n$ deficiency.

That $\mathrm{Zn}$ may have a role in the functioning of the mitotic spindle was proposed by Fujii (I955). $\mathrm{Zn}$ is also necessary for the normal morphology of neurotubules (Nickolson \& Veldstra, 1972), and the richness of the brain in these structures with its peculiar sensitivity to $\mathrm{Zn}$ depletion suggests that some of the abnormalities observed result from aberrations in structural or organizational processes. The paradox noted by Swenerton, Shrader \& Hurley (1969), that a reduction in thymidine labelling in $\mathrm{Zn}$-deficient foetuses is associated with an increased number of unlabelled mitotic figures in the neuroepithelium, may be resolved on the basis that $\mathrm{Zn}$ deficiency results in prolonged mitosis. In vitamin $B_{12}$-deficient rat foetuses, Newberne \& O'Dell (1959) observed a preponderance of mitotic figures in the aqueductal area of the brain and suggested that a metabolic block causing a longer period to complete mitosis results in a piling-up of mitotic figures as in colchicine treatment. The antimitotic drug, colchicine, is believed to exert its effect by combining with the protein dimer subunit of microtubules, so disturbing the dynamic equilibrium between aggregated and unaggregated states of microtubule assembly (Taylor, 1965; Weisenberg, Borisy \& Taylor, 1968 ). If $\mathrm{Zn}$ is required in some, as yet unidentified, process of stabilization of these molecules this would 
support the findings of Dinsdale \& Williams (1977) that an increased sensitivity to colchicine toxicity occurs in the duodenum of $\mathrm{Zn}$-deficient rats. A possible defect in microtubule-dependent insulin release in $\mathrm{Zn}$-deficient rats was suggested by Huber \& Gershoff (1973).

Any, or all, of the above-mentioned hypotheses may be relevant to the teratogenic effects of $\mathrm{Zn}$ deficiency. The continued development of the $\mathrm{Zn}$-deficient foetus, whether malformed or not, implies that synthesis of DNA, RNA and protein continues, even as the maternal $\mathrm{Zn}$ status declines. Relevant to this, however, are the findings of Williams, Davies \& Macdonald (unpublished results) which show that the specific rate of accretion of $\mathrm{Zn}$ (and $\mathrm{Cu}$ ) in the $12 \mathrm{~d}$ rat embryo is greater than that of body-weight. This implies that the absolute amount of $\mathrm{Zn}$ required at this time is less relevant than the rate of entry of that $\mathrm{Zn}$, a process which may greatly depend on the maintenance of an adequate maternal plasma $\mathrm{Zn}$ level.

On a more specific note it should be said that defects in otolith development in $\mathrm{Zn}$-deficient rat foetuses involving failure of formation of the calcite-containing otoconia may arise from a reduced activity of carbonic anhydrase $(E C$ 4.2.I.I) activity (Purichia \& Erway, 1972) and the skeletal defects in these foetuses may, in part, be due to a reduced activity of this enzyme.

\section{Trace metal deficiencies-simple or compound?}

In the foregoing sections, some of the effects of deficiencies of single elements have been described which are produced by the provision of controlled diets at specific periods of development. Naturally occurring mineral deficiencies are unlikely to be so severe or may not be so simple. Concurrent deficiencies of $\mathrm{Cu}$ and cobalt may occur in sheep and a combined $\mathrm{Zn}$ and iron deficiency occurs in humans (Prasad, Halstead $\&$ Nadimi, r $96 \mathrm{r}$ ). The identification of a deficiency state is also compounded by the fact that different elements may be needed at sequential steps in a biochemical process, a remarkable example of which is the synthesis of collagen. In this instance the initial chain elongation, dependent on Mg-activated aminoacyl t-RNA transferases, is followed by Fe-dependent hydroxylation and Mn-dependent glycosyl- or galactosylation. Cross-linking of the protein chains follows the $\mathrm{Cu}$-activated oxidation of lysyl residues and final stabilization of the protein network may be Zn-dependent (Chvapil, Elias, Ryan \& Zukoski, 1972). It would appear, therefore, that a deficiency of one element would not be without effects on another.

The heavy demands made by the developing foetus require that, if normal development is to continue, each metal must be present in the correct amount at the right time. Marginal deficiencies may result in irreversible damage to the developing tissues and multiple deficiencies may be catastrophic in their effect on the foetus or postnatal young. Little attention has been paid to the latter possibility, but it is worth noting that the presence of phytate (a common constituent of high-cereal, low-cost diets) reduces the retention by rats of $\mathrm{Fe}, \mathrm{Cu}$, 
$\mathrm{Zn}$ and $\mathrm{Mn}$ (Davies \& Nightingale, 1975) and is itself hydrolysed in the gut by the Zn-dependent phytase (N. T. Davies, personal communication).

It is relevant here to note that in many experiments on $\mathrm{Zn}$ deficiency in animals it is a common practice to use diets based on soya-bean meals or soya products in which phytate is a probable contaminant. The availability of any metal under these conditions must remain a vexing problem.

Finally, it has been shown by Bremner \& Davies (1976) that $\mathrm{Zn}$ is essential for the accumulation of $\mathrm{Cu}$ bound to liver metallothionein. Considerable amounts of both these metals are deposited in this form, presumably as early stores, in the foetal lamb liver (Bremner, Williams \& Young, 1977). These observations suggest that the specificity of the effects of single essential trace metal deficiencies requires further examination.

Depletion of the trace metal status of the body, notably in the instance of $\mathrm{Zn}$, may arise temporarily as a result of infection (Beisel, Pekarek \& Wannemacher, 1974) or, chronically, in such conditions as alcoholism. It was noted by Jones, Smith, Ulleland \& Streissguth (1973) that infants born to chronically alcoholic mothers were malformed. Of considerable interest is the observation of Burch, Hahn \& Sullivan (1975) that two out of four areas of the world (Egypt and Iran) notable for the high incidence of congenital abnormalities of the central nervous system are those in which a deficiency of $\mathrm{Zn}$ in the human population has been described and therefore, deficiencies of other essential minerals also are possible.

'We are what our mothers ate'

(Oberleas et al. 1972)

\section{REFERENCES}

Apgar, J. (1968). Am. F. Physiol. $215,160$.

Beisel, W. R., Pekarek, R. S. \& Wannemacher, R. W. (I974). In Trace Element Metabolism in Animals-2 p. 217 [W. G. Hoekstra, J. W. Suttie, H. E. Ganther \& W. Mertz, editors]. Baltimore, Maryland: University Park Press.

Bremner, I. \& Davies, N. T. (1976). Br. F. Nutr. 36, I01.

Bremner, I., Williams, R. B. \& Young, B. W. (1977). Br. F. Nutr. 38, 87.

Burch, R. E., Hahn, H. K. J. \& Sullivan, J. F. (1975). Clin. Chem. 21, 501 .

Carlton, W. W. \& Kelly, W. A. (1969). J. Nutr. 97, 42.

Chesters, J. K. (1974). In Trace Element Metabolism in Animals-2. p. 39 (W. G. Hoekstra, J. W. Suttie, H. E. Ganther \& W. Mertz, editors]. Baltimore, Maryland: University Park Press.

Chou, W. S., Savage, J. E. \& O'Dell, B. L. (1969). F. biol. Chem. 244, 5785.

Chvapil, M., Elias, S. L., Ryan, J. N. \& Zukoski, C. F. (1972). In Neurobiology of the Trace Metals Zinc and Copper. Suppl. I. p. I05 [C. C. Pfeiffer, editor]. New York: Academic Press.

Davies, N. T. \& Nightingale, R. (1975). Br. F. Nutr. 34, 243.

Dinsdale, D. \& Williams, R. B. (1977). Br. Y. Nutr. 37, 135 .

DiPaolo, R. V. \& Newberne, P. M. (1972). Trace Substances in Environmental Health-V p. 177 [D. D. Hemphill, editor]. Columbia, Missouri: University of Missouri.

Erway, L. C., Hurley, L. S. \& Fraser, A. S. (1966). Science 152, 1766.

Everson, G. J., Hurley, L. S. \& Geiger, J. F. (I959). F. Nutr. 68, 49.

Everson, G. J. \& Shrader, R. E. (1968). F. Nutr. 94, 89.

Everson, G. J., Tsai, H.-C. C. \& Wang, T. I. (1967). F. Nutr. 93, 533.

Falchuck, K. H., Fawcett, D. W. \& Vallee, B. L. (1975). F. cell Sci. 17, 57.

Fell, B. F., Leigh, L. C. \& Williams, R. B. (1973). Res. vet Sci. 14, 317.

Fell, B. F., Mills, C. F. \& Boyne, R. ( 1965$)$. Res. vet. Sci. 6, 170.

Fujii, T. (1955). J. Fac. Sci., Tokyo 7, 313. 
Gallagher, C. H. \& Reeve, V. E. (1971). Aust. f. exp. Biol. med. Sci. 49, 2 I.

Hambidge, K. M., Hambidge, C., Jacobs, M. \& Baum, J. D. (1972). Pediat. Res. 6, 868.

Hill, R. M., Holtkamp, D. E., Buchanan, A. R. \& Rutledge, E. K. (1950). F. Nutr. 4I, 359.

Howell, J. M. \& Davison, A. N. (1959). Biochem. F. 72, 365 .

Huber, A. M. \& Gershoff, S. N. (1973). f. Nutr. 103, 1739.

Hurley, L. S. (1968). Trace Substances in Environmental Health-11. p. 4 I [D. D. Hemphill, editor]. Columbia, Missouri: University of Missouri.

Hurley, L. S. \& Everson, G. J. (1959). Proc. Soc. exp. Biol. Med. 102, 360.

Hurley, L. S., Gowan, J. \& Swenerton, H. (197I). Teratology 4, 199.

Hurley, L. S. \& Shrader, R. E. (1972). In Neurobiology of the Trace Metals Zinc and Copper. Suppl. 1. p. 7 [C. C. Pfeiffer, editor]. New York: Academic Press.

Hurley, L. S. \& Shrader, R. E. (1975). Nature, Lond. 254, 427.

Hurley, L. S. \& Swenerton, H. (1966). Proc. Soc. $\exp$ Biol. Med. 123, 692.

Hurley, L. S., Wooten, E., Everson, G. J. \& Asling, C. W. (1960). F. Nutr. 71, 15.

Innes, J. R. M. \& Shearer, G. D. (1940). F. comp Pathol. 53, I.

Jones, K. L., Smith, D. W., Ulleland, C. N. \& Streissguth, P. (1973). Lancet, i, r267.

Leach, R. M. (1960). Ph.D. Thesis, Cornell University.

Leath, R. M. (1971). Fedn Proc. Fedn Am. Socs exp. Biol. 30, 991.

Mertz, W. (1974). Proc. Nutr. Soc. 33, 307.

Messer, H. H., Armstrong, W. D. \& Singer, L. (1972). Science $177,893$.

Mills, C. F. \& Williams, R. B. (1962). Biochem. 7. 85, 629 .

Newberne, P. M. \& O'Dell, B. L. (1959). Y. Nutr. 68, 343 .

Nickolson, V. J. \& Veldstra, H. (1972). Febs Letters 23, 303.

Oberleas, D., Caldwell, D. F. \& Prasad, A. S. (1972). In Neurobiology of the Trace Metals Zinc and Copper Suppl. I p. 83 [C. C. Pfeiffer, editor]. New York: Academic Press.

O'Dell, B. L. (1974). In Introduction to 'Clinical Applications of Zinc Metabolism' p. 5 [W. J. Pories, W. H. Strain, J. M. Hsu \& R. L. Woosley, editors]. Springfield, Illinois: C. C. Thomas.

O'Dell, B. L., Hardwick, B. C. \& Reynolds, G. (1961). f. Nutr. 73, 151 .

Prasad, A. S., Halstead, J. A. \& Nadimi, M. (1961). Am. F. Med. 31, 532.

Prasad, A. S., Miale, A., Farid, Z., Sandstead, H. H., Schulert, A. \& Darby, W. J. (1963). Arch. intern Med. I1 $1,407$.

Purichia, N. \& Erway, L. C. (1972). Develop. Biol. 27, 395.

Rojas, M. A., Dyer, I. A. \& Cassatt, W. A. (1965). F. anim. Sci. $24,664$.

Scrutton, M. C., Griminger, P. \& Wallace, J. C. (1972). J. biol. Chem. 247, 3305.

Shrader, R. E. \& Everson, G. J. (1967). J. Nutr. 9r, 453.

Shrader, R. E. \& Everson, G. J. (1968). Y. Nutr. 94, 269.

Siegel, R. C., Pinnell, S. R. \& Martin, G. R. (1970). Biochemistry 9, 4486.

Swenerton, H., Shrader, R. E. \& Hurley, L. S. (1969). Science 166, 1014.

Taylor, E. W. (1965). Y. cell Biol. 25, 145.

Tsai, H.-C. C. \& Everson, G. J. (1967). J. Nutr. 91, 447.

Tucker, H. F. \& Salmon, W. D. (I955). Proc. Soc. $\operatorname{exp~Biol.~Med.~88,~} 6$ I 3.

Underwood, E. J. (1971). Trace Elements in Human and Animal Nutrition $3^{\text {rd }}$ ed. p. 99. New York and London: Academic Press.

Weisenberg, R. C., Borisy, G. G. \& Taylor, E. W. (I968). Biochemistry 7, 4466.

Williams, R. B., Demertzis, P. \& Mills, C. F. (1973). Proc. Nutr. Soc. 32, 3 A.

Xilinas, M. E. \& Lagarde, D. (1975). Lancet, i, 863.

Note added in proof. Since this article was written a report has appeared (Tao, S. \& Suttie, J. W. (1976). F. Nutr. 106, III5) which suggests that the apparent essentiality of fluoride for reproduction in female mice as previously observed by Messer et al. (1972) was due to a pharmacological effect of $F$ in improving iron utilization in a diet only marginally sufficient in Fe. 